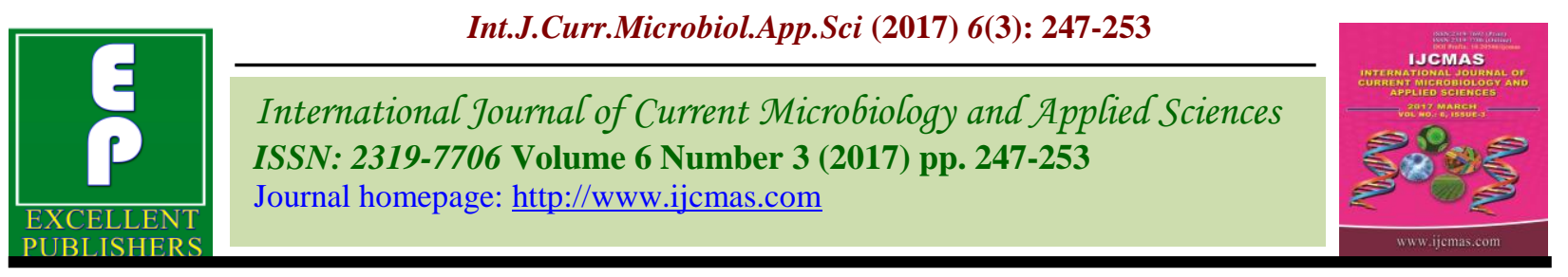

Original Research Article

https://doi.org/10.20546/ijcmas.2017.603.027

\title{
Imazethapyr Effects on Soil Enzyme Activity and Nutrient Uptake by Weeds and Greengram (Vigna radiata $\mathbf{L}$.)
}

\author{
Girdhari Lal $^{1 *}$, S.M. Hiremath ${ }^{2}$ and Kailash Chandra ${ }^{3}$ \\ ${ }^{1}$ Department of Agronomy, Institute of Agricultural Sciences, Banaras Hindu University, \\ Varanasi-221005, India \\ ${ }^{2}$ Department of Agronomy, ARS, Gadag, UAS, Dharwad-580 005 (Karnatka), India \\ ${ }^{3}$ Institute of Agricultural Sciences, Banaras Hindu University, Varanasi-221005, India \\ *Corresponding author
}

\begin{abstract}
A B S T R A C T
Keywords

Imazethapyr, Soil enzyme activity, NPK, Early postemergence, Greengram.

Article Info

Accepted:

10 January 2017

Available Online:

10 March 2017

A field experiment was conducted to examine the effect of early post-emergence herbicide Imazethapyr $10 \%$ SL on soil enzyme activity (Dehydrogenase, Urease and Phosphatase) and nutrient uptake by weeds and greengram at Main Agricultural Research Station, Dharwad during kharif 2014. The treatments comprised of Imazethapyr 50g, Imazethapyr $62.5 \mathrm{~g}$, Imazethapyr $75 \mathrm{~g}$, Imazethapyr $50 \mathrm{~g}$ with adjuvant, Imazethapyr $62.5 \mathrm{~g}$ with adjuvant, Imazethapyr 75g with adjuvant, Quizalofop-ethyl $1000 \mathrm{ml}$, standard check (2IC + 2HW), weedy check and weed free check and was laid out in Randomized Complete Block Design with three replications. Weed free check $\left(T_{10}\right)$ recorded significantly higher dehydrogenase, urease and phosphatase activity recorded at seven $\& 15$ days after spraying compared to all other treatments but was on par with $\mathrm{T}_{8}$. Among the different doses, higher dose of Imazethapyr (75 g a.i. ha ${ }^{-1}$ with adjuvant) recorded lower dehydrogenase, urease and phosphatase activity of soil at seven and 15 days after spraying. Weed free check $\left(\mathrm{T}_{10}\right)$ recorded significantly higher uptake of nutrients (NPK) by greengram compared to all other treatments but was on par with $\mathrm{T}_{8}$. Among the different doses, higher dose of Imazethapyr (75 g a.i. ha ${ }^{-1}$ with adjuvant) recorded higher uptake of nutrients (NPK) by greengram. Nutrients (NPK) uptake by weeds was higher in weedy check, but significantly lower in weed free, standard check and Imazethapyr treated plots.
\end{abstract}

\section{Introduction}

Imazethapyr is a broad spectrum herbicide used as early post-emergence in pulses, oilseeds and leguminous crops. Imazethapyr is an imidazole compound used as a selective herbicide. The compound controls weeds by reducing the levels of three branched-chain aliphatic amino acids, isoleucine, leucine and valine, through the inhibition of aceto-lactate synthase (ALS), an enzyme common to the biosynthetic pathway for these amino acids.
Imazethapyr is used as post emergence or early post emergence at 20-25 DAS of soybean, greengram, blackgram and sunflower to control a variety of weeds.

However, intensive use of herbicides often lead to accumulation of active ingredients (or metabolites) of herbicides in agricultural soils. These herbicides have potential to deteriorate the soil and water (of nearby 
aquifers, rivers, lakes) and ultimately affect the soil microbial activity Nakatani et al., 2014. The quantity of herbicide available to the soil micro flora depends on different factors like: Soil nutrients, $\mathrm{pH}$, temperature, and moisture content. To determine the ecological toxicity of herbicides against soil microorganisms, the activities of different soil enzymes have to be analyzed. The soil enzyme activity represents the total population of soil micro flora. The soil enzyme activity reacts faster than physical activity of soil. Therefore, they can beused as an early warning bioindicator against the changes occur in soil (Baćmaga et al., 2015; Franco- Andreu et al., 2016; Saha Ajoy et al., 2016. So far, contrasting results have been observed by various researchers evaluating the impact of imazethapyr on soil microbial biomass and enzymatic activities. Lupwayi et al., 2004 reported that application of Imazethapyr decreased the soil microbial biomass, microbial diversity and carbon content.

Nutrients are very much essential for growth and development for green gram and there deficiency leads to decrease the crop yield. Therefore, it is necessary to know the uptake of nutrients by crop and weeds. Komal et al., 2015 reported that Imazethapyr reduces density of weeds, resulting lower uptake of NPK by weeds and higher by crop.

\section{Materials and Methods}

A field experiment with 10 treatments and three replications laid out in randomized complete block design was undertaken at Main Agricultural Research Station, University of Agricultural Sciences, Dharwad (Karnataka) during kharif season of 2014. The treatments comprised of Imazethapyr 10\% SL @ $50 \mathrm{~g}$ a.i. ha ${ }^{-1}\left(\mathrm{~T}_{1}\right)$, Imazethapyr 10\% SL @ $62.5 \mathrm{~g}$ a.i. ha ${ }^{-1}\left(\mathrm{~T}_{2}\right)$, Imazethapyr 10\% SL @ $75 \mathrm{~g}$ a.i. ha ${ }^{-1}\left(\mathrm{~T}_{3}\right)$, Imazethapyr 10\% SL @ 50 g a.i. ha ${ }^{-1}+$ adjuvant @ $2.0 \mathrm{ml}$ litre $^{-1}$ of water $\left(\mathrm{T}_{4}\right)$, Imazethapyr 10\% SL @ $62.5 \mathrm{~g}$ a.i. ha ${ }^{-1}+$ adjuvant @ $2.0 \mathrm{ml}$ litre $^{-1}$ of water $\left(\mathrm{T}_{5}\right)$, Imazethapyr 10\% SL @ 75 g a.i. ha ${ }^{-1}+$ adjuvant @ $2.0 \mathrm{ml}$ litre ${ }^{-1}$ of water $\left(\mathrm{T}_{6}\right)$, Quizalofop-ethyl 5\% EC @ $1000 \mathrm{ml}$ litre $^{-1}$ of water $\left(\mathrm{T}_{7}\right)$, standard check $(2 \mathrm{IC}+2 \mathrm{HW}$ at 20 and 40 DAS) $\left(\mathrm{T}_{8}\right)$, weedy check $\left(\mathrm{T}_{9}\right)$ and weed free check $\left(\mathrm{T}_{10}\right)$. The experimental soil was black clayey soil (Vertisol) with the $\mathrm{pH}$ 7.4 , organic carbon $\left(8 \mathrm{~g} \mathrm{~kg}^{-1}\right)$, available $\mathrm{N}$ $\left(248 \mathrm{~kg} \mathrm{ha}^{-1}\right)$, available $\mathrm{P}_{2} \mathrm{O}_{5}\left(25.55 \mathrm{~kg} \mathrm{ha}^{-1}\right)$ and available $\mathrm{K}_{2} \mathrm{O}$ (396 kg ha $\left.{ }^{-1}\right)$.

Green gram variety 'Nirmal Gold (NVL-1)' was sown on $14^{\text {th }}$ July 2014 at $30 \times 10 \mathrm{~cm}$ spacing using seed rate of $12 \mathrm{~kg} \mathrm{ha}^{-1}$. The recommended fertilizers i.e. $25: 50 \mathrm{~kg} \mathrm{ha}^{-1} \mathrm{~N}$ and $\mathrm{P}_{2} \mathrm{O}_{5}$ were applied at the time of sowing. The total rainfall received during crop growth period was $604.2 \mathrm{~mm}$ and was well distributed. The early post-emergence herbicide Imazethapyr was sprayed at 23 DAS and other herbicide such as Quizalofopethyl was sprayed at the same time.

\section{Soil sampling}

The soil sampling was done randomly from each plot i.e., 7 and 15 days after spraying of herbicides. Samples were taken from the top $(0-15 \mathrm{~cm})$ layer of soil using a soil auger and mixed thoroughly to prepare one homogeneous composite sample after removing plant materials.

\section{Soil enzyme activity assay}

Dehydrogenase (DHA) activity was estimated by monitoring the rate of production of triphenylformazan (TPF) from substrate 2, 3, 4-tri-phenyl tetrazolium chloride (TTC) (Casida et al., 1964). Phosphatase activity in soil was assayed from the amount of $\rho$ nitrophenol released (Evazi and Tabatabai, 1979). The procedure adopted to determine 
the urease activity of soil was essentially the same as adopted by Pancholy and Rice (1973) except the ammonia liberated due to hydrolysis used in the reaction mixture was determined by nesslerization as described by Jackson (1973).

\section{Estimation of $\mathbf{N}, \mathbf{P}$ and $\mathrm{K}$ uptake by crop and weed}

To estimate the uptake of $\mathrm{N}, \mathrm{P}$ and $\mathrm{K}$ by crop and weeds, samples were collected at 60 DAS and at harvest. The samples were oven dried at $65^{\circ} \mathrm{C}$ and ground in Willey mill to pass through two mm sieve. The two mm sieved samples were used for the estimation of nitrogen, phosphorus and potassium content in crop and weeds.

Nitrogen uptake by crop and weeds were determined by digesting the plant samples with suitable acid mixture of concentrated sulphuric acid. The digested samples were distilled by Microkjeldhal method in an alkaline condition and titrated against standard acid Piper (2002).

Phosphorus was estimated by Vanedomolybdate method in diacid mixture as detailed by Jackson (1973). The intensity of the colour developed was measured in a spectrophotometer, using blue filter. Potassium content was estimated from diacid digest material using Flame Photometer as described by Muhr et al., (1965) and was expressed as percentage $\mathrm{K}$. The nutrient content and dry weight were used to calculate the total uptake of nutrients (N P K) and expressed in $\mathrm{kg} \mathrm{ha}^{-1}$.

Nutrient uptake $\left(\mathrm{kg} \mathrm{ha}^{-1}\right)=$

Nutrient content (\%)

100

\section{Results and Discussion}

Effect of Imazethapyr as EPOE herbicide on soil enzyme activity

\section{Dehydrogenase activity (DHA) $\left(\mu \mathrm{g} \mathrm{TPFg}^{-1}\right.$ soil day $^{-1}$ )}

Dehydrogenase is as an intra-cellular enzyme and related to microbial respiratory processes. Hence, death of cells or propagation leads to increase or decrease of DHA, and therefore, it is an indication of overall behavior of microbial population of the soils. Among the herbicide treated plots application of Imazethapyr@75 g a.i ha ${ }^{-1}+$ Adjuvant @ 2.0 $\mathrm{ml} \mathrm{ha}^{-1}$ of water recorded lower dehydrogenase activity (Table 1) at seven days after spray but was on par with rest of the doses. The higher dehydrogenase activity was observed in weed free check when compared to all other treatments, but on par with Standard check. Quizalofop-ethyl @ $1000 \mathrm{ml} \mathrm{ha}^{-1}$ also recorded lower dehydrogenase activity but higher than Imazethapyr treated plots.

The similar trend was observed at 15 days after spray of herbicides but DHA was increased. Imazethapyr decreased the DHA from the 7 th day onwards after the treatment and persisted only up to the 15th days in peanut (Saha Ajoy et al., 2016). Moreno et al., (2007) said that DHA was stable possibly due to a stress process of soil microorganisms which helped to maintain constant values. But at higher doses of Imazethapyr suppression of DHA was observed, which may be due to the lethal action of Imazethapyr on soil microorganisms (Jyot et al., 2015), which, in turn, affect the enzymatic chemical process owing high concentration of herbicides as well as the toxicity of the metabolites, produced from the herbicides at later stages (Sabale et al., 2015). 


\section{Urease activity ( $\mu \mathrm{g} \mathrm{NH}_{4}-\mathrm{N} \mathrm{g}^{-1}$ soil day $^{-1}$ )}

Urease, a key hydrolyzing enzyme, mediates the hydrolysis of urea into carbon dioxide and ammonia and hence plays a very important role in the nitrogen cycle in soils. Urease activity of the soil was significantly influenced by application of herbicides. Application of Imazethapyr @ $75 \mathrm{~g}$ a.i ha ${ }^{-1}+$ Adjuvant@ $2.0 \mathrm{ml} \mathrm{ha}^{-1}$ of water as EPOE herbicide recorded lower Urease activity (Table 1) at seven days after spray. The higher Urease activity was observed in weed free check when compared to all other treatments, but on par with Standard check. Quizalofop-ethyl @ $1000 \mathrm{ml} \mathrm{ha}{ }^{-1}$ also recorded lower Urease activity but higher than Imazethapyr treated plots. The similar trend was observed at 15 days after spray of herbicides but urease activity was increased compared to 7 days after spraying and the effect of herbicide was decreased. Many studies reported that urease activity reduced or decreased due to herbicide application (Riah et al., 2014; Saha Ajoy et al., 2016 reported that urease activity decreased with Imazethapyr ( 7 to 15 days after spray) at different doses. Majumdar et al., (2010) revealed that urease activity of soil inhibited by the application of Quizalofop-p-ethyl.

\section{Phosphatases activity ( $\mu \mathrm{g} \mathrm{pnpg}^{-1}$ soil $\mathrm{hr}^{-1}$ )}

At seven days after spray of herbicides, the higher phosphatase activity was observed in weed free check. However, Standard check was on par with weed free check. Application of Imazethapyr $75 \mathrm{~g}$ a.i ha ${ }^{-1}$ with or without adjuvant recorded lower phosphatase activity.

Table.1 Soil enzyme activity as influenced by weed control treatments in green gram

\begin{tabular}{|c|c|c|c|c|c|c|}
\hline \multirow{2}{*}{ Treatment } & \multicolumn{2}{|c|}{$\begin{array}{c}\text { Dehydrogenase } \\
\text { activity } \\
\left(\mu \mathrm{TPF}_{\mathbf{1}^{-1}} \text { soil day }\right.\end{array}$} & \multicolumn{2}{|c|}{$\begin{array}{c}\text { Urease activity } \\
\left(\mu \mathrm{g} \mathrm{NH}_{4} \mathrm{~N} \mathrm{~g}^{-1} \text { soil day }{ }^{-1}\right)\end{array}$} & \multicolumn{2}{|c|}{$\begin{array}{c}\text { Phosphatases activity } \\
\left(\mu \mathrm{g} \text { pnp } \mathrm{g}^{-1} \text { soil hr }^{-1}\right)\end{array}$} \\
\hline & $\begin{array}{l}7 \text { days } \\
\text { after } \\
\text { sprayin } \\
\text { g }\end{array}$ & $\begin{array}{l}15 \text { days } \\
\text { after } \\
\text { spraying }\end{array}$ & $\begin{array}{c}7 \text { days } \\
\text { after } \\
\text { spraying }\end{array}$ & $\begin{array}{l}15 \text { days } \\
\text { after } \\
\text { spraying }\end{array}$ & $\begin{array}{l}7 \text { days after } \\
\text { spraying }\end{array}$ & $\begin{array}{l}15 \text { days } \\
\text { after } \\
\text { spraying }\end{array}$ \\
\hline $\mathbf{T}_{1}$ & 25.17 & 34.88 & 3.12 & 3.92 & 94.41 & 118.45 \\
\hline $\mathbf{T}_{2}$ & 25.00 & 34.32 & 2.96 & 3.88 & 92.23 & 117.23 \\
\hline $\mathbf{T}_{3}$ & 23.15 & 32.21 & 2.68 & 3.66 & 86.42 & 107.36 \\
\hline $\mathbf{T}_{4}$ & 24.83 & 34.07 & 3.08 & 3.90 & 94.25 & 116.88 \\
\hline $\mathbf{T}_{5}$ & 24.27 & 33.36 & 2.92 & 3.84 & 90.67 & 114.42 \\
\hline$T_{6}$ & 23.84 & 31.73 & 2.66 & 3.56 & 85.66 & 106.47 \\
\hline $\mathbf{T}_{7}$ & 30.85 & 32.32 & 3.28 & 4.15 & 88.37 & 112.32 \\
\hline $\mathbf{T}_{8}$ & 38.35 & 41.03 & 4.62 & 4.55 & 112.42 & 110.57 \\
\hline $\mathbf{T}_{9}$ & 34.08 & 35.02 & 4.28 & 4.20 & 102.95 & 103.85 \\
\hline $\mathbf{T}_{10}$ & 38.46 & 41.24 & 4.68 & 4.58 & 116.46 & 113.33 \\
\hline S.Em \pm & 0.93 & 1.08 & 0.07 & 0.11 & 3.20 & 3.52 \\
\hline CD (5\%) & 2.78 & 3.21 & 0.23 & 0.33 & 9.51 & $\mathrm{NS}$ \\
\hline
\end{tabular}


Table. 2 Nitrogen, phosphorus and potash uptake $\left(\mathrm{kg} \mathrm{ha}^{-1}\right)$ by weeds and greengram as influenced by weed control treatments

\begin{tabular}{|c|c|c|c|c|c|c|c|c|c|c|c|c|}
\hline \multirow{3}{*}{ Treatment } & \multicolumn{6}{|c|}{ NPK uptake $\left(\mathrm{kg} \mathrm{ha}^{-1}\right)$ by weeds } & \multicolumn{6}{|c|}{ NPK uptake (kg ha $\left.{ }^{-1}\right)$ by greengram } \\
\hline & \multicolumn{3}{|c|}{60 DAS } & \multicolumn{3}{|c|}{ At harvest } & \multicolumn{3}{|c|}{60 DAS } & \multicolumn{3}{|c|}{ At harvest } \\
\hline & $\mathbf{N}$ & $\mathbf{P}$ & $\mathbf{K}$ & $\mathbf{N}$ & $\mathbf{P}$ & $\mathbf{K}$ & $\mathbf{N}$ & $\mathbf{P}$ & $\mathbf{K}$ & $\mathbf{N}$ & $\mathbf{P}$ & $\mathbf{K}$ \\
\hline $\mathbf{T}_{1}$ & 11.30 & 2.45 & 8.32 & 11.47 & 2.62 & 8.63 & 61.76 & 15.87 & 57.84 & 37.65 & 9.87 & 36.58 \\
\hline $\mathbf{T}_{2}$ & 10.39 & 2.28 & 7.58 & 10.52 & 2.43 & 7.92 & 67.53 & 16.94 & 62.78 & 38.03 & 10.00 & 36.45 \\
\hline $\mathbf{T}_{3}$ & 9.08 & 2.06 & 6.91 & 9.19 & 2.20 & 7.20 & 74.91 & 21.23 & 75.79 & 41.06 & 11.84 & 42.22 \\
\hline $\mathbf{T}_{4}$ & 9.08 & 1.98 & 6.46 & 9.21 & 2.12 & 6.79 & 70.16 & 18.39 & 67.09 & 39.94 & 10.81 & 39.09 \\
\hline $\mathbf{T}_{5}$ & 8.19 & 1.89 & 6.07 & 8.32 & 2.02 & 6.38 & 79.81 & 21.90 & 76.52 & 44.49 & 12.34 & 42.95 \\
\hline$T_{6}$ & 4.90 & 1.11 & 3.67 & 4.96 & 1.18 & 3.89 & 88.71 & 23.81 & 85.17 & 50.36 & 13.67 & 49.06 \\
\hline $\mathbf{T}_{7}$ & 10.83 & 2.33 & 7.67 & 10.97 & 2.49 & 8.02 & 71.40 & 18.52 & 65.44 & 39.81 & 10.48 & 37.34 \\
\hline $\mathbf{T}_{8}$ & 3.56 & 0.87 & 2.78 & 3.61 & 0.93 & 2.93 & 93.44 & 26.21 & 90.19 & 53.14 & 15.20 & 51.76 \\
\hline $\mathbf{T}_{9}$ & 28.91 & 6.26 & 20.22 & 29.50 & 6.68 & 21.27 & 54.03 & 13.82 & 50.96 & 32.69 & 8.49 & 31.77 \\
\hline $\mathbf{T}_{10}$ & 0.64 & 0.16 & 0.50 & 0.70 & 0.18 & 0.57 & 93.90 & 26.31 & 90.25 & 54.78 & 15.61 & 52.68 \\
\hline S.Em \pm & 1.04 & 0.22 & 0.70 & 1.08 & 0.24 & 0.85 & 2.58 & 0.96 & 2.37 & 1.51 & 0.41 & 1.51 \\
\hline $\mathrm{CD}(5 \%)$ & 3.11 & 0.67 & 2.09 & 3.22 & 0.71 & 2.53 & 7.69 & 2.85 & 7.06 & 4.49 & 1.24 & 4.49 \\
\hline
\end{tabular}

All other doses of Imazethapyr have recorded lower soil phosphatase activity, but higher dose has more effect than lower dose. Quizalofopethyl@ $1000 \mathrm{ml} \mathrm{ha}^{-1}$ also recorded lower phosphatase activity but higher than Imazethapyr treated plots. At 15 days after spray of herbicides there was no significant difference was observed in phosphatase activity (Table 1). Strong inhibition of acid phosphate activity was observed due to application of Imazethapyr (Perucci et al., 2000), whereas increase in the activity was 10 times. Majumdar et al., (2010) reported that early negative effect on acid phosphatase activity and alkaline phosphatase activity were observed due to application of quizalofop-p-ethyl. Many researchers observed that some herbicides may inhibit acid phosphatae and stimulate alkaline phosphatase activity and vice versa (Cycon et al., 2012). Alkaline phosphatase activity was increased by application of Imazethapyr after initial inhibition at higher doses and at later stages, but prolonged inhibition was observed for acid phosphatase (Saha Ajoy et al., 2016).

\section{Effect of Imazethapyr herbicide on nutrient (NPK) uptake by weeds}

At 60 DAS, significantly lower uptake of nitrogen $\left(0.64 \mathrm{~kg} \mathrm{ha}^{-1}\right)$ was recorded in weed free check compared to all other treatments. However, Standard check also recorded lower uptake of nitrogen $\left(3.56 \mathrm{~kg} \mathrm{ha}^{-1}\right)$ but on par with Imazethapyr@ $@ 75 \mathrm{~g}$ a.i ha ${ }^{-1}+$ Adjuvant @ 2.0 $\mathrm{ml} \mathrm{litre}{ }^{-1}$ of water $\left(4.90 \mathrm{~kg} \mathrm{ha}^{-1}\right)$. This is due to the effective control of weeds by herbicides. Significantly higher nitrogen uptake $(28.91 \mathrm{~kg}$ $\mathrm{ha}^{-1}$ ) was recorded in weedy check, which results from higher number of weeds present in this treatment. Similar trend was observed at harvest. At 60 DAS, significantly lower uptake of phosphorus $\left(0.16 \mathrm{~kg} \mathrm{ha}^{-1}\right)$ was recorded in weed free check. However, Standard check also recorded lower uptake of phosphorus $(0.87 \mathrm{~kg}$ $\mathrm{ha}^{-1}$ ), but on par with Imazethapyr @ $75 \mathrm{~g} \mathrm{a.i}$ ha $^{-1}+$ Adjuvant @ $2.0 \mathrm{ml}$ litre $^{-1}$ of water (1.11 $\left.\mathrm{kg} \mathrm{ha}^{-1}\right)$. Significantly higher phosphorus uptake $\left(6.26 \mathrm{~kg} \mathrm{ha}^{-1}\right)$ was recorded in weedy check. Similar trend was observed at harvest. At 60 DAS, significantly lower uptake of potassium $\left(0.50 \mathrm{~kg} \mathrm{ha}^{-1}\right)$ was recorded in weed free check $\left(\mathrm{T}_{10}\right)$ compared to all other treatments. However, Standard check (2 IC $+2 \mathrm{HW}$ at 20 and $40 \mathrm{DAS})\left(\mathrm{T}_{8}\right)$ also recorded lower uptake of potassium $\left(2.78 \mathrm{~kg} \mathrm{ha}^{-1}\right)$ compared to $\mathrm{T}_{5}, \mathrm{~T}_{4}, \mathrm{~T}_{3}$, $\mathrm{T}_{2}, \mathrm{~T}_{7}, \mathrm{~T}_{1}$ and $\mathrm{T}_{9}$ treatments, but on par with $\mathrm{T}_{6}-$ Imazethapyr@75 g a.i ha ${ }^{-1}+$ Adjuvant@2.0 $\mathrm{ml}$ litre $^{-1}$ of water $\left(3.67 \mathrm{~kg} \mathrm{ha}^{-1}\right)$. Significantly higher potassium uptake $\left(20.22 \mathrm{~kg} \mathrm{ha}^{-1}\right)$ was recorded in weedy check $\left(\mathrm{T}_{9}\right)$. Similar trend was 
observed at harvest. The results on uptake of nutrients (NPK) by weeds are in line with the findings of Habimana Sylvestre et al., 2013; Vijayalaxmi et al., 2012; Parchant et al., 2015 and Komal et al., 2015.

\section{Effect of Imazethapyr herbicide on nutrient (NPK) uptake by greengram}

Significant variations were observed with NPK uptake by greengram recorded at 60 DAS and harvest. At 60 DAS, nitrogen uptake by greengram was observed significantly higher in weed free check $\left(93.90 \mathrm{~kg} \mathrm{ha}^{-1}\right)$. However, Standard check ( $\left.93.44 \mathrm{~kg} \mathrm{ha}^{-1}\right)$ and Imazethapyr @ $75 \mathrm{~g}$ a.i. ha ${ }^{-1}+$ Adjuvant @ $2.0 \mathrm{ml}$ litre $^{-1}$ of water $\left(88.71 \mathrm{~kg} \mathrm{ha}^{-1}\right)$ remained on par with weed free check. Weedy check recorded significantly lower uptake of nitrogen by greengram $\left(54.03 \mathrm{~kg} \mathrm{ha}^{-1}\right)$. Similar trend was observed at harvest. At 60 DAS, phosphorus uptake by greengram was observed significantly higher in weed free check $\left(26.31 \mathrm{~kg} \mathrm{ha}^{-1}\right)$. However, Standard check $\left(26.21 \mathrm{~kg} \mathrm{ha}^{-1}\right)$ and Imazethapyr @75 g a.i. ha ${ }^{-1}+$ Adjuvant @ 2.0 $\mathrm{ml}$ litre $^{-1}$ of water $\left(23.81 \mathrm{~kg} \mathrm{ha}^{-1}\right)$ remained on par with weed free check $\left(\mathrm{T}_{10}\right)$. Weedy check recorded significantly lower uptake of phosphorus by greengram (13.82 $\left.\mathrm{kg} \mathrm{ha}^{-1}\right)$. Similar trend was observed at harvest. At 60 DAS, potassium uptake by greengram was observed significantly higher in weed free check $\left(90.25 \mathrm{~kg} \mathrm{ha}^{-1}\right)$, but on par with Standard check (90.19 $\mathrm{kg} \mathrm{ha}^{-1}$ ) and Imazethapyr @ $75 \mathrm{~g}$ a.i. ha ${ }^{-1}+$ Adjuvant @ $2.0 \mathrm{ml}$ litre $^{-1}$ of water (48.91 kg ha ${ }^{-1}$ ). Weedy check recorded significantly lower uptake of potassium by greengram (30.15 kg ha ${ }^{-1}$ ). Similar trend was observed at harvest. The higher uptake of NPK by greengram in weed free, standard check and Imazethapyr treated treatments were due to reduction in dry matter of weeds and less cropweed competition for different resources likelight, moisture, nutrients and $\mathrm{CO}_{2}$ (Table 2). The results on nutrients (NPK) uptake by greengram are in conformity with the findings of Parchant et al., 2015; Komal et al., 2015; Shruthi et al., 2015; Habimana Sylvestre et al., 2013 and Vijayalaxmi et al., 2012.
In conclusion Application of Imazethapyr @ 75 g a.i. ha ${ }^{-1}+$ adjuvant @ $2 \mathrm{ml}$ litre $^{-1}$ of water recorded significantly lower Dehydrogenase, Urease and Phosphatase activity due to toxic effect of Imazethapyr. Higher soil enzyme activity was observed where no herbicides were applied. Application of Imazethapyr @ $75 \mathrm{~g}$ a.i. ha $^{-1}+$ adjuvant @ $2 \mathrm{ml} \mathrm{litre}^{-1}$ of water recorded higher uptake of nutrients by greengram and lower by weeds.

\section{References}

Baćmaga, M., Borowik, A., Kucharski, J., Tomkiel, M., Wyszkowska, J. 2015. Microbial and enzymatic activity of soil contaminated with a mixture of diflufenican + mesosulfuron-methyl + iodosulfuron-methylsodium. Environ. Sci. Pollut. Res., 22: 643-656.

Casida, L.E., Klein, D.A., Santoro, T. 1964. Soil science. J. Soil Sci., 98(6): 371-376.

Cycon, M., Piotrowska-Seget, Z., Kozdroj, J. 2012. Responses of indigenous microorganisms to a fungicidal mixture of mancozeb and dimethomorph added to sandy soils. Int. Biodeter. Biodegrr., 64: 316-323.

Evazi, Z. and Tabatabai, M.A. 1979. Phosphatase in soils. Soil Biol. Biochem., 9: 167 - 172.

Franco-Andreu, L., Gómez, I., Parrado, J., García, C., Hernández, T., Tejada, M. 2016. Behavior of two pesticides in a soil subjected to severe drought. Effects on soil biology. Appl. Soil. Ecol., 105: 1724.

Habimana, S., Kalyana Murthy, K. N., Shankaralingappa, B. C., Sanjay, M. T., Ramachandra, C. 2013. Nutrient uptake and yield of soybean (Glycine max L.) as influenced by pre and post-emergence herbicides. European J. Experimental Bio., 5: 33-40.

Jackson, M. L. 1973. Soil Chemical Analysis, Prentice Hall of India Pvt. Ltd., New Delhi.

Jyot, G., Mandal, K., Singh, B. 2015. Effect of 
dehydrogenase, phosphatase and urease activity in cotton soil after applying thiamethoxam as seed treatment. Environ. Monit. Assess, 187(5): 1-7.

Komal, Singh, S.P., Yadav, R.S. 2015. Effect of weed management on growth, yield and nutrient uptake of greengram. Indian $J$. Weed Sci., 47(2): 206-210.

Lupwayi, N.Z., Harker, K.N., Clayton, G.W., Turkington, T.K., Rice, W.A., O'Donovan, J.T. 2004. Soil microbial biomass and diversity after herbicide application. Can. J. Plant Sci., 84: 677685.

Majumdar, B., Saha, A.R., Sarkar, S., Maji, B., Mahapatra, B.S. 2010. Effect of herbicides and fungicides application on fibre yield and nutrient uptake by jute (Corchorus olitorius), residual nutrient status and soil quality. Indian J. Agric. Sci., 80(10): 878-883.

Muhr, G.R., Datta, N.P., Shankarambramoney, R., Lelley, V.R., Donahue, R.L. 1965. Soil Testing in India. USAID, New Delhi, 47-77.

Nakatani, A.S., Fernandes, M.F., De Souza, R.A., da Silva, A.P., dos Reis-Junior, F. B., Mendes, I.C., Hungria, M. 2014. Effects of the glyphosateresistance gene and of herbicides applied to the soybean crop on soil microbial biomass and enzymes. Field Crops Res., 162: 20-29.

Pancholy, S.K., Rice, F.L. 1973. Soil enzyme in relation to old field succession: amylase, cellulose, invertage, dehydrogenese and urease, Soil Sci. Soc. Am. Proc., 47-50.

Perucci, P., Dumontet, S., Bufo, S.A., Mazzatura, A., Casucci, C. 2000. Effects of organic amendment and herbicide treatment on soil microbial biomass. Biol.
Fert. Soils, 32: 17-23

Piper, C. S. 2002. Soil and Plant Analysis, Hans Publ. Bombay, India.

Prachand, Smita, K.J., Kubde, Sujata Bankar, 2015. Effect of chemical weed control on weed parameters, growth, yield attributes, yield and economics in soybean (Glycine max). Trends in Biosci., 8(2): 539-542.

Riah, W., Laval, K., Laroche-Ajzenberg, E., Mougin, C., Latour, X., TrinsoutrotGattin, I. 2014. Effects of pesticides on soil enzymes: a review. Environ. Chem. Lett., 12: 257-273.

Sabale, R.P., Shabeer, T.P.A., Utture, S.C., Banerjee, K., Oulkar, D.P., Adsule, P. G., Deshmukh, M. B. 2015. Kresoxim methyl dissipation kinetics and its residue effect on soil extra-cellular and intra-cellular enzymatic activity in four different soils of India. J. Environ. Sci. Health, Part B, 50(2): 90-98.

Saha, A., Bhaduri, D., Pipariya, A., and Jain, N.K. 2016. Influence of Imazethapyr and Quizalofop-p-ethyl application on microbial biomass and enzymatic activity in peanut grown soil. Environ. Sci. Pollution Res., 23(23): 23758-23771.

Shruthi, G.K., Salakinkop, S.R., Patil, H.Y. 2015. Effect of sequential application of pre and post-emergence herbicides on nutrients uptake by crop and weeds in kharif greengram. Int. J. Trop. Agric., Vol.33(2): 703-708.

Vijayalaxmi, G.S., Hiremath, S.M., Hosmath, J.A., Patil, P.L., Doddamani, M.B. 2012. Sequential application of pre and post emergence herbicides in soybean (Glycine max L.) Karnataka J. Agric. Sci., 25(2): 262-263.

\section{How to cite this article:}

Girdhari lal, S.M. Hiremath and Kailash Chandra. 2017. Imazethapyr Effects on Soil Enzyme Activity and Nutrient Uptake by Weeds and Greengram (Vigna radiata L.). Int.J.Curr.Microbiol.App.Sci. 6(3): 247-253. doi: https://doi.org/10.20546/ijcmas.2017.603.027 